\title{
LAND USE AND MITIGATION EFFECTS ON BARRIER BEACH EROSION IN STORMS: CASE STUDY IN RHODE ISLAND
}

\author{
Naser AlNaser ${ }^{1}$, Annette R. Grilli ${ }^{1}$, Stephan T. Grilli ${ }^{1}$, Christopher Baxter ${ }^{1,2}$, Aaron Bradshaw ${ }^{2}$, Brian Maggi ${ }^{2}$
}

\begin{abstract}
Sea Level Rise (SLR) and storm intensification lead to re-evaluating inundation assessments along the North Atlantic US shoreline. A particular effort is devoted to assessing coastal community risk to "100-year storm" events in Rhode Island, US, using a chain of state-of-the-art storm surge, wave propagation, and coastal erosion 2D models. Damage risks imposed on infrastructures and services incited US federal and state agencies to come up with innovative engineering solutions to improve coastal resiliency while preserving natural coastal and marine environments. This study critically evaluates available design tools used to assess the performance of two types of Natural and Natural Based Features (NNBFs) for coastal protection: natural vegetated barrier islands and dunes reinforced with Geotextile Sand-filled Containers (GSCs), on urbanized barrier islands. Comparative analyses with field data identifies the capabilities and limitations of phase averaging and phase resolving hydro-morphodynamic models used for simulating bed level changes in dissipative beaches, during 3 Sallenger storm regimes. Recommendations are provided on modeling approaches for simulating effects of vegetation and using GSCs to limit coastal erosion.
\end{abstract}

Keywords: Vegetation; Geotextile Sand-filled Containers; Dune; Erosion; XBeach

\section{INTRODUCTION}

The combination of SLR with increased storm frequency and intensity (Woodruff et al., 2013) has led local and international management agencies to reassess the vulnerability of coastal communities and the potential damage inflicted by extreme storms to infrastructures and services (e.g., Katehis 2015; Spaudling et al., 2016; Grilli et al. 2017a). Particular attention has been given to marine geohazards and extreme storm events, due to their massive financial impacts (e.g., Blake et al., 2013; Grilli et al. 2016). In the US, many agencies, such as the Rhode Island (RI) Coastal Resource Management Council (CRMC) have had policies reducing or preventing the use of hard-structures for coastal protection, as such traditional solutions have had undesirable effects on natural shoreline processes (Nederhoff, 2014). Consequently, various Natural and Natural Based Features (NNBF) have been proposed for coastal protection. Traditionally, vegetation has been identified as a natural means of dissipating wave energy and minimizing coastal erosion, through induced turbulence and friction (e.g., Woodhouse, 1978; Terrados and Duarte 2000; Moller and Spencer 2002). Similarly, the role of beach dunes as coastal barriers against storm surge and wave set-up has been increasingly understood by coastal planners (Grilli et al.; 2017b). Recently, NNBFs such as Geotextile Sand-filled Containers (GSCs) have been proposed as protection methods against flood, inundation, and wave overtopping during storms (e.g., Restall et al. 2000; Connell 2016); however, validated assessment tools and design codes are still lacking for he latter. While semi-empirical formulations based on laboratory measurements combined with numerical simulations have been developed, few studies have assessed the performance of GSCs and other NNBFs in the field.

The objective of this study is to: (1) evaluate the relevance of numerical models for assessing the field performance of selected NNBFs; (2) perform a case study of NNBFs at a selected RI test site. In this paper, we focus on the first part while part 2 will be presented in a future paper. The proposed numerical modeling approach interactively solves for coupled processes between NNBFs and their environment, using the stateof-the-art morphodynamic model XBeach (Roelvink et al., 2009). We consider cases studies along the North East Atlantic coast, which is made of dissipative sandy beaches and barrier islands (e.g., New-Jersey to Rhode Island). We first evaluate the protection offered by dunes and vegetation (i.e., "Natural Structures" (NS)) and then consider Hybrid Structures (HS; i.e., reinforced dunes with GSCs). Both NS and HS are tested and assessed for extreme storm events, here represented by the local 100-year storm. On this basis, we discuss the most appropriate tool based on the combination of shoreline morphology and wave climate.

\section{Background}

Recent studies have assessed the risk posed to coastal communities in RI by the 100-year storm event. While initial 2D modeling following standard procedures predicted potential damage to coastal infrastructures, further studies considering SLR projections and using more accurate wave models showed a dramatic increase in potential damage, due to a significant expansion of the inundation (Grilli et al., 2017; Spaulding

\footnotetext{
${ }^{1}$ Depart. of Ocean Engineering, University of Rhode Island, Narragansett, RI, 02882, USA

${ }^{2}$ Depart. of Civil Engineering, University of Rhode Island, Kingston, RI, 02881, USA
} 

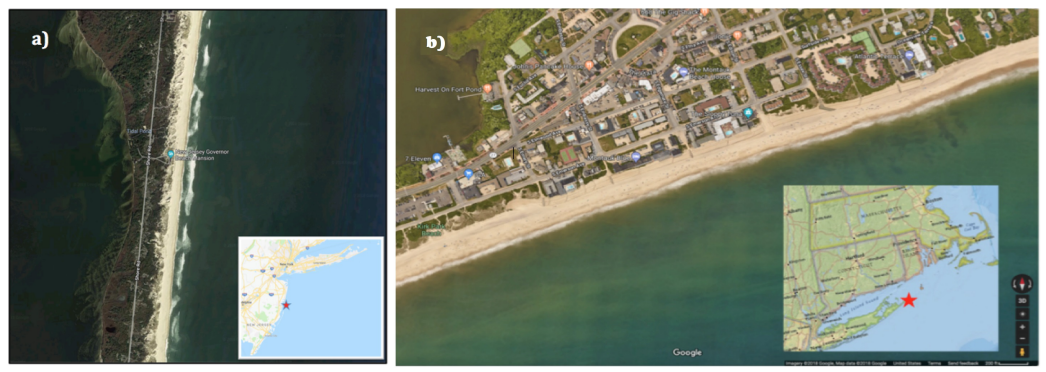

Figure 1: Aerial images showing location of Site: a) 1 and b) 2 (Taken from Google Maps 2018).

et al., 2017). To reduce structural damage due to flooding and wave overtopping, several mitigation scenarios were considered, such as rising the First Furnished Floor Elevations (e.g., U.S Corps of Engineer at selected RI South Shore Sites) or beach re-nourishment (Grilli et al.; 2017). Subsequently, more advanced $2 \mathrm{D}$ morphodynamic studies were performed to investigate the stability of the dune system and barrier islands and better quantify the risk faced by coastal communities when these natural features (NS) are eroded during extreme events (Schambach et al., 2018). Scenarios addressing the impact of land cover type confirmed the importance of vegetation in mitigating the impact of extreme storms. While some barrier islands have been preserved as natural parks, unfortunately, many others have been opened to development, often resulting in high-density residential areas. The increase in storm frequency, combined with this urbanization of barrier islands, prevents the natural restoration of the beach system and limits its role as a protective buffer zone. This results in an increased risk for coastal communities, which has strongly affected flood insurance rates. Recently, the US Army Corps of Engineers (USACE) reconstructed a dune system and reinforced it with GSCs in Montauk, NY, in an attempt to limit beach erosion and protect the dense community settled behind the dune barrier from extreme storms, a common situation along the US Atlantic Coastline (USACE-NAN 2014). This type of GSC dune reinforcement to improve coastal protection has been considered at RI sites.

\section{Objectives}

The morphodynamic model XBeach is used to evaluate two NNBF methods of reducing the erosion of dissipative beaches and barrier beaches: (1) vegetation and (2) dune reinforcement with GSC structures. The performance of the model is assessed by comparing results with field measurements at selected test sites. The primarily targeted site is the southern RI shoreline, which is defined by a mixed of natural and highly urbanized barrier islands; however, other sites characterized by similar dissipative beaches, dune geomorphology, and urbanization development are considered for model simulations and calibration, based on data availability. Two sites were selected for each NNBF, vegetation and GSC, respectively:

- Site 1: Ocean City's, NJ undeveloped barrier island (Fig. 1a), which has a large back dune ( $400 \mathrm{~m})$ covered with a mix of tall grass, shrubs, forests and intertidal vegetation at the bay side, similar to the RI south shore. This site was surveyed before and after Hurricane Sandy (2012) and this data was used to evaluate the modeling of vegetation effects with XBeach. The dune elevation varies between 4 and $8 \mathrm{~m}$ (NAVD88), allowing to test the model accuracy for each of Sallenger's (2000) modes of erosions (swash, collision, overwash and inundation) which all occurred during Hurricane Sandy, depending on the crest elevation of the dune segment.

- Site 2: Montauk's, NY town beach (Fig. 1b), which is south of RI and has a similar wave climate. This is the first US site reinforced with GSC structures by the USACE and we have been collecting data at the site since tropical storm (TS) Hermine impacted it in 2016, causing exposure and instability of the GSCs n some parts of the structure.

\section{METHODS}

\section{Mitigating erosion on natural barrier island with vegetation}

An earlier study (Schambach et al., 2018) showed that dune erosion is strongly restricted when the dunes are covered with vegetation. This was shown using a variable Manning friction coefficient $n$ in $\mathrm{XBeach}$, based on land cover. Here, we further explore the use of the Manning $n$ to simulate vegetation 
Table 1: Recommended Manning roughness values for specific land cover types (Wamsley et al., 2009).

\begin{tabular}{|c|c||c|c|}
\hline Land Cover Type & Manning $n$ & Land Cover Type & Manning $n$ \\
\hline \hline Open Water & 0.020 & Shrub Land & 0.050 \\
Low Residential & 0.070 & Grassland & 0.034 \\
High Residential & 0.140 & Woody Wetland & 0.100 \\
Deciduous and Mixed Forests & 0.120 & Herbaceous Wetland & 0.040 \\
Evergreen Forest & 0.150 & & \\
\hline
\end{tabular}

cover, by increasing friction in the model (Wamsley et al., 2009, 2010). Alternately, we evaluate vegetation effects represented by a drag force in XBeach (Mendez and Losada 2004). In the following, we present a brief overview of the model and a summary of each of the approaches implemented for including vegetation effects in the model.

Erosion modeling. XBeach ("eXtreme Beach behavior") is a 2D coupled hydro-morphodynamic model predicting erosion and morphological changes of barrier islands along dissipative beaches for specified storms. The model can simulate the coastal response (dune erosion, breaching, avalanching, overwash and accretion) and bed level changes during Sallenger's (2000) 4 erosion regimes: swash, collision, overwash and inundation (Roelvink et al. 2009, 2010). Two short wave modules are available, which are coupled with a sediment transport and a morphology model: a phase-averaged and a phase-resolved, corresponding to the Surfbeat (SB) and Non-hydrostatic (NH) modes, respectively. The model is highly parameterized and we used parameters value similar to those used and validated by Schambach et al. (2018), with the exception of wave asymmetry, which is modified according to Elsayed et al. (2017). Further details of $\mathrm{XBeach}$ can be found in reference.

Vegetation modeling. The standard approach to account for vegetation effects on flow velocity is to use a spatially variable Manning friction coefficient $n$, function of land cover (e.g., Kothyari et al., 1997; Van Rijin 1989; Wamsley et al. 2009; Schambach et al., 2018); this yields a bed friction coefficient, $C_{b f}=\sqrt{g n^{2} / h^{1 / 3}}$ where $g$ is gravity and $h$ is water depth. Values of $n$ for specific land cover are given in Table 1, based on Wamsley et al.'s (2009) study.

An alternative method is to consider the drag force caused by individual plants on the instantaneous flow field, in the form of a Morison et al. (1950) type equation (Dalrymple et al., 1984). Mendez and Losada (2004) expanded Dalrymple et al.'s (1984) theory to include wave randomness, dissipation due to wave breaking, and bottom variations. They however neglected stem swaying motiond and inertia forces, and lumped the uncertainty of the stem flexibility and relative velocity between plant and water particles into an empirical drag coefficient (Maza et al., 2013), expressed as,

$$
D_{v}=\frac{1}{2 \sqrt{\pi}} \rho C_{D} N b_{v}\left(\frac{g k}{2 \sigma}\right)^{3} \frac{\sinh ^{3}(k \alpha h)+3 \sinh (k \alpha h)}{3 k \cosh ^{3} k h} H_{\mathrm{rms}}^{3}
$$

with $D_{v}$ the time-averaged rate of energy dissipation per unit horizontal area induced by the vegetation, $\rho$ the fluid density, $C_{D}$ the drag coefficient, $N$ the number of vegetation stems per unit horizontal area, $b_{v}$ the plant area per unit height of each vegetation stem normal to the velocity, $\sigma$ the wave angular frequency, $\alpha$ the relative vegetation height (\%) relative to the local water depth $h, k$ is the wavenumber, and $H_{\mathrm{rms}}$ the root-mean-square wave height.

The appeal of this physics-based approach is however mitigated by its applicability. Indeed, the vegetated area needs to be accurately defined with a vegetation density and stem size as well as with a drag coefficient specific to the mechanical properties of the plant (e.g., Stratigaki et al. 2011; Maza et al. 2013; Vargus-Luna et al. 2015). The variety of vegetation and lack of available corresponding drag coefficients prevented us from applying Mendez and Losada's (2004) formulation to our entire site and we only applied it to a small section of the site, covered with tall grass similar to Spartina Alterniflora; for the latter, we used the drag coefficient of Smith et al. (2016) based on Anderson and Smith's (2014) experiments, $C_{D}=0.22+910 / \mathrm{Re}$. 
Table 2: Damage levels $\left(L_{D}\right)$ for reinforced dunes with GSCs

\begin{tabular}{|c|c|c||c|c|c|}
\hline$L_{D}$ & Description & $\begin{array}{c}\text { Associated } \\
\text { Risk }\end{array}$ & $L_{D}$ & Description & $\begin{array}{c}\text { Associated } \\
\text { Risk }\end{array}$ \\
\hline \hline 0 & $\begin{array}{c}\text { Accretion or no } \\
\text { change of the profile }\end{array}$ & No Risks & 4 & $\begin{array}{c}\text { Hydraulic instability } \\
\text { of GSCs }\end{array}$ & $\begin{array}{c}\text { Structural failure } \\
\text { and instability }\end{array}$ \\
\hline 1 & Berm erosion & $\begin{array}{c}\text { Replenish. } \\
\text { costs }\end{array}$ & 5 & $\begin{array}{c}0.5 \text { m scour } \\
\text { development }\end{array}$ & $\begin{array}{c}\text { Structural failure } \\
\text { and instability }\end{array}$ \\
\hline 2 & $\begin{array}{c}\text { GSCs cover layer } \\
\text { erosion or the dune }\end{array}$ & $\begin{array}{c}\text { Replenish. } \\
\text { costs }\end{array}$ & 6 & $\begin{array}{c}\text { Runup over crest } \\
\text { elevation, overtopping } \\
\text { and struc. submergence }\end{array}$ & $\begin{array}{c}\text { Flooding and } \\
\text { damage to coastal } \\
\text { front development }\end{array}$ \\
\hline 3 & Exposure of GSCs & $\begin{array}{c}\text { Replenish. } \\
\text { costs }\end{array}$ & & & \\
\hline
\end{tabular}

Table 3: Summary of stability equations used to assess the stability of GSC

\begin{tabular}{|c||c|c|}
\hline Equations & $\begin{array}{c}\text { GSCs located in } \\
\text { the structure slope }\end{array}$ & $\begin{array}{c}\text { GSCs locates at } \\
\text { the structure crest }\end{array}$ \\
\hline \hline Oumeraci et & $N_{s}^{\text {slope }}=H_{s} /\left\{D\left(\frac{\rho_{E}}{\rho_{w}}-1\right)\right\}$ & $N_{s}^{\text {crest }}=H_{S} /\left\{D\left(\frac{\rho_{E}}{\rho_{w}}-1\right)\right\}$ \\
& $<2.75 / \sqrt{\xi_{0}}$ & $<0.79+0.09 R_{c} / H_{s}$ \\
al. (2013) & $l_{c}^{\text {sliding }}<u^{2}$. & $\begin{array}{c}l_{c}^{\text {overturning }}<u^{2} . \\
\text { Recio }\end{array}$ \\
Oumeraci (2008) & $\frac{0.5 K S_{C D} C_{D}+2.5 \mu K S_{C L} C_{L}}{\mu K S_{R} \Delta g-K S_{C M} C_{M} \partial u / \partial t}$ & $\frac{0.05 K O_{C D} C_{D}+1.25 K O_{C L} C_{L}}{0.5 K O_{R} \Delta g-0.1 K O_{C M} C_{M} \partial u / \partial t}$ \\
\hline
\end{tabular}

\section{Mitigating erosion on natural barrier islands using GSCs}

The validity of XBeach to estimate erosion damage in the presence of GSCs is assessed by applying the model to Site 2. Simulations are performed for TS Hermine and predicted bed level changes are compared with post survey measurements, using standard morphological skill parameters; predicted damage levels are assessed using both Oumeraci (2003) and Recio and Oumeraci's stability formula (2008). Damage levels refer to Dassanayake and Oumeraci's classifications (2013), in which damage is classified into: classification 1, where damage is identified at the scale of a single GSC; and classification 2 where damage is identified at the scale of the entire GSC structure. Some authors (Shirlal and Mallidi, 2015) summarize results in a level 3 classification, where the total fraction of damaged structure is estimated as the percentage of GSCs displaced with respect to total GSCs in the structure. Here, we introduce a level 4 classification where the full beach is considered and the erosion on the entire beach ecosystem and GSC structure is considered (Table 2). Semi-empirical hydraulic stability formulas for GSC structures were developed in the early 2000 based on flume experiments (Oumeraci et al., 2003), following the earlier hydraulic stability formulas of Hudson (1956) and Wouters (1998) for non-deformable structures. Later, based on similar experimental studies, these formulations were updated to be applicable to deformable structures (e.g., Recio and Oumeraci 2007; Recio and Oumeraci 2008, 2009; Dassanyake and Oumeraci 2012).

Despite their similar functionality, various GSCs have specific mechanical properties under cyclic loading, such as permeability, flexibility, and sand-fill ratio. For example, a stress-strain analysis reveals that the increase of the GSC effective area during uprush contributes to larger drag forces and moments acting on the GSC during uprush rather than downrush. As a result, steeper structural slopes are found to be more stable due to an increased contact area between the GSC layers. Numerical simulations for a large number of structural configurations has led to semi-empirical formulas for 2 failure modes (Recio and Oumeraci, 2008). A summary of stability equations from the literature is given in Table 3. In this study, we compare results of Hudson and Recio and Oumeraci (2008) stability equations to GSC structures at Site 2 to field measurements made after TS Hermine. Parameters of these equations (Table 3) were computed with XBeach: significant wave height $\left(H_{s}\right)$, flow velocity $(u)$ and acceleration $(\partial u / \partial t)$.

\section{Scenarios and performance assessment evaluation}

Table 4 gives a summary of design tools tested for each NNBF, at each test site. The ability of these approaches to accurately simulate the level of protection provided is assessed by applying several skill 
Table 4: Tested design tools for each NNBF

\begin{tabular}{|c||c|c|c|}
\hline Process & Method & Site 1 & Site 2 \\
\hline \hline Erosion Modeling & Surfbeat mode [SB] (phase averaging) & $\mathrm{x}$ & $\mathrm{x}$ \\
& Nonhydrostatic [NH] (phase resolving) & $\mathrm{x}$ & \\
\hline Vegetation Modeling & Bed friction parameterization & $\mathrm{X}$ & $\mathrm{x}$ \\
& Semi-empirical formulations based & $\mathrm{x}$ & \\
& on plant induced forces & & \\
\hline Geotextile Sand-filled & Hudson's based Stability equations & & $\mathrm{x}$ \\
Containers (GSCs) Modeling & Semi-empirical formulations for GSCs & & $\mathrm{x}$ \\
\hline
\end{tabular}

Table 5: Summary of skill parameters used to assess the simulation results

\begin{tabular}{|c||c|c|c|}
\hline $\begin{array}{c}\text { Skill } \\
\text { Param. }\end{array}$ & $\begin{array}{c}\text { Conceptual assessment } \\
\text { SK }\end{array}$ & $\begin{array}{c}\text { Optimal } \\
\text { value }\end{array}$ & Formulation \\
\hline \hline eroded volume & 1 & $\mathrm{SK}=1-\sqrt{\sum_{i=1}^{N}\left(V_{c}-V_{0}\right)^{2}} / \sqrt{\sum_{i=1}^{N} V_{0}^{2}}$ \\
\hline BSS & $\begin{array}{c}\text { Morphological skill to compute } \\
\text { bed level change }\end{array}$ & 1 & $\mathrm{BSS}=1-$ \\
\hline BI & $\begin{array}{c}\text { Difference in central tendencies } \\
\text { of computed and observation }\end{array}$ & 0 & $\sum_{i=1}^{N}\left(z_{b}^{\text {comp }}-z_{b}^{\text {meas }}\right)^{2} / \sum_{i=1}^{N}\left(z_{b}^{\text {initial }}-z_{b}^{\text {meas }}\right)^{2}$ \\
\hline RMSE & $\begin{array}{c}\text { Accuracy of computed results } \\
\text { Bl }\end{array}$ & 0 & $\frac{1}{N} \sum_{i=1}^{N}\left(z_{b}^{\text {comp }}-z_{b}^{\text {meas }}\right)$ \\
\hline
\end{tabular}

parameters, which are presented in Table 5: the Brier Skill Score (BSS), Bias Score (BI), the Root Mean Square Error (RMSE), and the skill of the model defined by Gallager et al (1998), which compares the relative value of eroded volume.

\section{DATA AND MODEL SET UP}

Bathy-topographic and hydrodynamic data (i.e., wave characteristics, storm surge and tide elevation) are required to simulate erosion processes with XBeach, for the 4 Sallenger regimes. Large scale data sets were obtained from US federal agencies, such as the National Oceanographic and Atmospheric Agency (NOAA), US Army Corps of Engineers (USACE), and the US Geological Survey (USGS) for areas affected by Hurricane Sandy (2012), which were collected as part of a national assessment of change in coastal hazard. High-resolution bathy-topographic data was used near the area of interest, to capture the spatial variability of dunes and ultimately identify vulnerable areas. Wave and water level measurements were taken from NOAA's buoys at a hourly time-step. To determine the XBeach's offshore boundary conditions at the selected computational grid domain, additional hydrodynamic models of storm surge (ADCIRC) and wind-wave generation and propagation (SWAN, STWAVE) were applied.

Site 1 is located $20 \mathrm{~km}$ north of the landfall location of Hurricane Sandy (2012). Pre- and post-LiDAR measurements of bed level changes were used to construct XBeach computational grid and compare to simulation results. The computational grid has a $2 \times 2 \mathrm{~m}$ resolution near the dune and $2 \times 5 \mathrm{~m}$ offshore. The entire duration of the simulation is 72 hours, with landfall occurring after 48 hours. The start date/time of the simulation is Oct. 28, 2012 00:00:00 UTC, and end date/time Oct. 31, 2012 00:00:00 UTC. Peak wave conditions obtained from a coupled model (SWAN and ADCIRC) at the offshore boundary were a significant wave height of $H_{s}=6.5 \mathrm{~m}$, spectral peak period $T_{p}=16 \mathrm{~s}$, mean direction $\theta=170$ degrees in nautical convention, and a peak water level (storm surge) of $2.7 \mathrm{~m}$ (NAVD88). Additional information on land cover type was obtained from the USGS website.

For Site 2, a combination of surveys (i.e., USACE as-built surveys, URI post construction surveys, LiDAR surveys) were used to generate a $0.5 \times 1.2 \mathrm{~m}$ XBeach grid and identify locations of sea front buildings. Post-TS Hermine (2016) measurements were made by the authors along 22 transects at the site. The 
entire duration of the simulation was 96 hours, starting from Sept. 4, 2016 00:00:00 UTC. Peak conditions occurred around Sept. 6, 2016 00:00:00 UTC (i.e., 49th hour of simulation). Wave characteristics at the offshore location were obtained from STWAVE using NOAA's offshore buoy (Station ID 44017) and tidal gauge (Station ID 8510560) in close proximity of the project site. Peak conditions had a significant wave height of $H_{s}=4.5 \mathrm{~m}$, spectral peak period $T_{p}=11 \mathrm{~s}$, and a peak water level of $0.8 \mathrm{~m}$ (NAVD88).

\section{RESULTS}

Mitigating erosion on natural barrier islands with vegetation (Site 1)

Erosion modeling. Pre- and post-field measurements at Site 1 during Hurricane Sandy (2012) showed significant bed level changes, with a large alongshore variation that can be explained by the different Sallenger regimes experienced by different segments of the barrier island. While the northern section of the study site has a relatively elevated dune crest, which prevented an overwash regime to occur during the storm, the crest elevation progressively lowers southward, which caused waves to overtop the dune, thus progressively transitioning the erosion regime from overwash to inundation mode. The northern section of the site, with the highest dune crest elevations, experienced a collision mode, which resulted in the seaward (cross-shore) deposition of a large volume of sand eroded from the dune face. By contrast, the lower elevation southern region experienced an overtopping mode, resulting in dune breaching, landward sediment deposition, and inland flooding.

a)

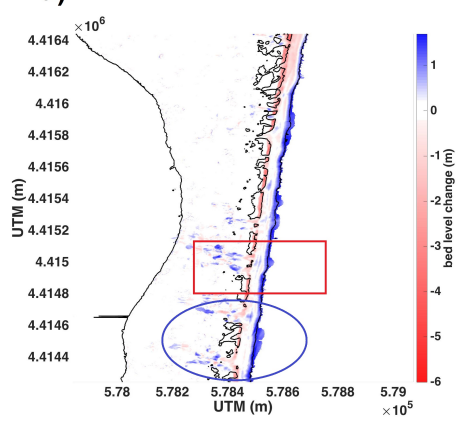

b)

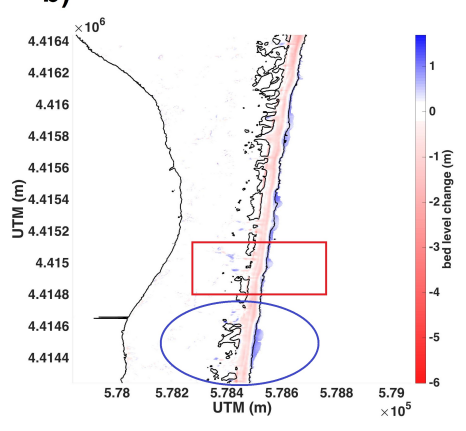

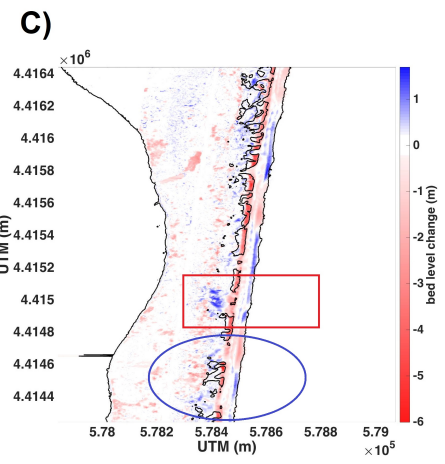

Figure 2: XBeach simulation results for Hurricane Sandy (2012) showing final computed bed level changes. a) and b) refer to SB and NH, whereas c) shows actual bed level changes from measurements. Red boxes indicate locations of overwash fans, and blue circles indicate locations of sensitive areas. Contour lines are displayed for 0 and $6 \mathrm{~m}$.

Figure 2 shows a comparison with field measurements of bed level changes computed with XBeach using the phase-averaged "Surf Beat mode" $(\mathrm{SB})$ or the phase-resolving $(\mathrm{NH})$ mode, for land cover types parameterized with the bed friction ( $n$ value). Results show that the NH mode more accurately predicts the sediment distribution patterns, but underestimates the eroded volume from the dune. In contrast, the SB mode more accurately estimates the eroded volume, but overestimates the landward distance of sediment deposition. Despite inaccuracies in sediment distribution patterns and landward distance of sediment deposition, the SB mode better predicts the morphological evolution of the dune system along the various segments of the site. Figure 3 shows a comparison of crest elevation computed with both modes, which is a critical factor for determining vulnerable locations. In this figure, the performance of each approach in estimating the alongshore dune crest lowering is further illustrated by representing it using 3 colors, green, yellow, and red, as described in Table 6; a quantitative summary of this color-coding is given in Table 7.

To assess the model performance for Sallenger regimes (collision, overwash and inundation) the site was subcategorized into 3 areas representatives of these regimes, based on dune crest elevation and runup values. The northern area having higher dune elevations was referred to as Area A. The middle region, which experienced crest lowering, but not landward sediment deposition, was referred to as Area B. Finally, the most vulnerable region to the south, in which overwash and inundation regimes occurred, was referred to as Area C. The sub-categorization of the site is illustrated in Fig. 4, in which results along typical crosssections through the dunes are also provided, together with pre- and post-storm field survey data, confirming for all regimes the optimality of SB. 
a)

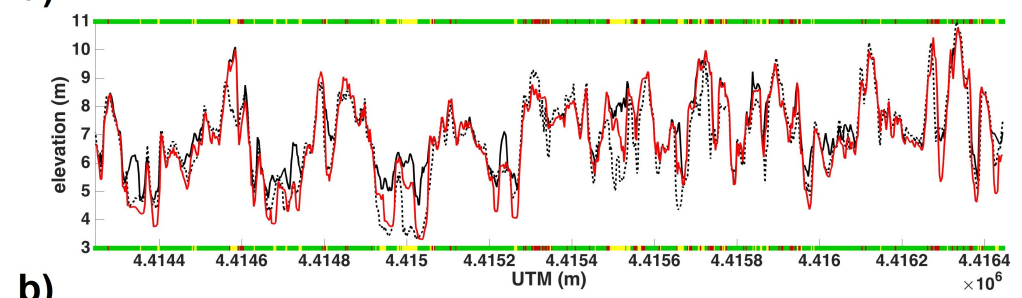

b)

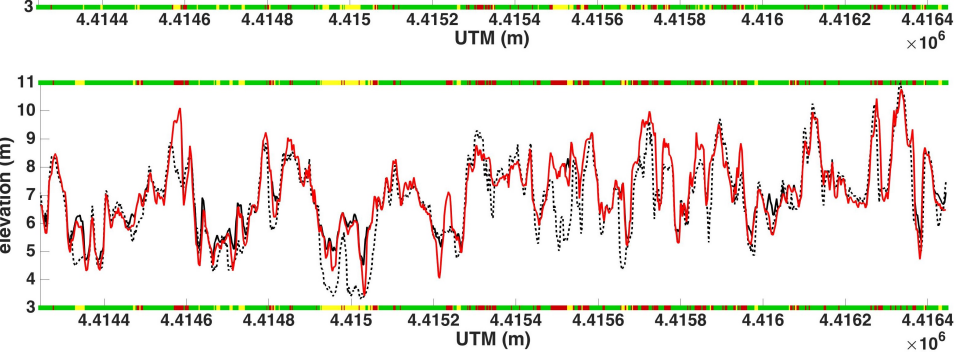

Figure 3: Pre- (solid black) and post-survey (dashed black) measurements of dune crest elevation, compared to XBeach simulations (red line). a) and b) are results for SB and NH, respectively. The meaning of green, yellow and red shading is defined in Table 6.

Table 6: Description of the performance indicators used to evaluate the estimation of dune crest elevations

\begin{tabular}{|c||c|c|c|}
\hline Index value & Color & Description & Performance Indicator \\
\hline \hline 1 & Red & Did not predict locations of crest lowering & Poor \\
\hline 2 & Yellow & $\begin{array}{c}\text { Accurate prediction of dune crest lowering the } \\
\text { but with error greater than } 0.5 \mathrm{~m}\end{array}$ & Good \\
\hline 3 & Green & $\begin{array}{c}\text { Accurate prediction of dune crest lowering } \\
\text { with error less than } 0.5 \mathrm{~m}\end{array}$ & Excellent \\
\hline
\end{tabular}

Table 7: Summary of the average index values for predicting dune crest elevations

\begin{tabular}{|c||c|c|c|c|}
\hline Scenarios & No. of Red locations & No. of yellow locations & No. of Green locations & Avg index \\
\hline \hline SB & 106 & 133 & 695 & 2.63 \\
\hline NH & 201 & 123 & 610 & 2.43 \\
\hline
\end{tabular}

A summary of skill parameters computed on model results is given in Table 8 for Areas A, B and C, which can be used to assess the accuracy of each computation modem(SB or NH). In Area A where the collision regime mainly dominated, both models show a "reasonable" morphological skill, according to Van Rijin et al.'s (2003) classification, with a BSS of 0.34 and 0.42 for SB and NH, respectively. This is due to an underestimation of the erosion rate on the dune foreface, as indicated by the low SK value. In Area $\mathrm{B}$, both models underestimate the eroded volume and consequently the dune crest lowering, resulting in a "poor" BSS of -1.72 for SB. However, since NH gives better sediment transport patterns, a slightly better BSS of 0.29 is achieved. Similarly, in Area C, NH yields a "poor" BSS value of -2.30 , due to a significant underestimation of the eroded volume, which prevents the escalation of the storm regime to overwash and inundation. This however was better simulated in SB, resulting in a better BSS value of 0.19.

Vegetation modeling. Mendez and Losada's (2004) formulation, implemented in XBeach's vegetation module, provides a reasonable estimation of the energy dissipation for both SB and NH modes, in agreement with Smith et al. (2016). Figure 5 shows (in a non-dimensional form) the distance across Spartina Alterniflora necessary to reduce the incident wave height by $50 \%$. However the SB mode systematically requires more vegetation distance to limit the wave height than $\mathrm{NH}$. A skill assessment of this approach as well as of the standard bed friction parameterization, were performed to compare morphological predictions of dune and barrier island sections during inundation. A typical cross section of the barrier island at test Site 
a)

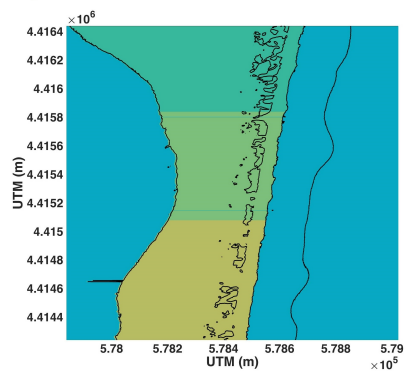

b)
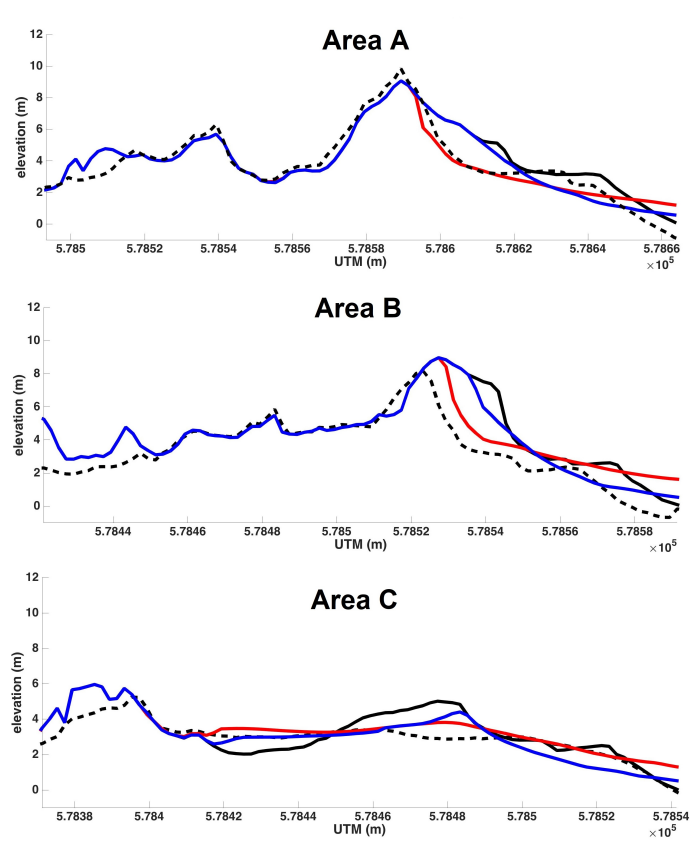

Figure 4: Sub-categorization of Site 1 according to Sallenger Regimes. a) Areas: A (top, dark green), B (middle, light green) and $\mathrm{C}$ (low, yellow) representing collision, overwash and inundation regimes, respectively, during Superstorm Sandy. Black contour lines are shown for, -4, 0 , and $6 \mathrm{~m}$ (NAVD88). b) Typical cross-sections in Areas A, B, C, in which SB (red line) and NH (blue line) results are compared with pre(solid black) and post- (dashed black) surveys.

Table 8: Summary results of evaluation performance for Scenario 1 and 2 for Sallengerõs regimes in the sub-aerial region

\begin{tabular}{|c||c|c|c|c|c|c|c|c|c|c|c|c|}
\hline \multicolumn{1}{|l|}{ Sce. } & \multicolumn{4}{|c|}{ Area A } & \multicolumn{4}{c|}{ Area B } & \multicolumn{4}{c|}{ Area C } \\
\cline { 2 - 13 } & SK & $\begin{array}{c}\text { Mean } \\
\text { BSS }\end{array}$ & $\begin{array}{c}\text { Mean } \\
\text { B1 } \\
(\mathrm{m})\end{array}$ & $\begin{array}{c}\text { Mean } \\
\text { RMSE } \\
(\mathrm{m})\end{array}$ & SK & $\begin{array}{c}\text { Mean } \\
\text { BSS }\end{array}$ & $\begin{array}{c}\text { Mean } \\
\text { B1 } \\
(\mathrm{m})\end{array}$ & $\begin{array}{c}\text { Mean } \\
\text { RMSE } \\
(\mathrm{m})\end{array}$ & SK & $\begin{array}{c}\text { Mean } \\
\text { BSS }\end{array}$ & $\begin{array}{c}\text { Mean } \\
\text { B1 } \\
(\mathrm{m})\end{array}$ & $\begin{array}{c}\text { Mean } \\
\text { RMSE } \\
(\mathrm{m})\end{array}$ \\
\hline \hline SB & 0.5 & 0.34 & 0.01 & 0.18 & 0.35 & -1.72 & 0.03 & 0.10 & 0.12 & 0.19 & 0.03 & 0.08 \\
\hline NH & 0.5 & 0.42 & 0.05 & 0.21 & 0.38 & 0.29 & 0.05 & 0.12 & 0.18 & -2.30 & 0.03 & 0.09 \\
\hline
\end{tabular}

1 was submerged using two relative depths, and subjected to an incident wave height with $H_{s}=5 \mathrm{~m}$ and $T_{p}=10 \mathrm{~s}$. The subaerial vegetation cover was assumed to be consistent with Spartina Alterniflora, similar to Smith et al. (2016). The drag coefficient used in the vegetation module is as described above, as part of Eq. (1), while the Manning $n$ was interpolated from Table 1 (the $n$ value selected for Spartina Alterniflora was 0.04$)$. A sensitivity of model results to $n \in[0.04-0.15]$ is shown in Fig. 6. We see, the vegetation module provides similar results to simulations with $n=0.15$; this value, however, strongly restricts sediment suspension rates, which led to an optimal $n \simeq 0.04$, representative of Spartina Alterniflora.

\section{Mitigating erosion on urbanized barrier islands with GSCs (Site 2)}

TS Hermine bed level changes. Analyses of bed level changes in XBeach simulations of TS Hermine indicate an intense erosion of the berm and GSC cover layer. Since TS Hermine hit the coastline in collision regime, avalanching was the principal process responsible for beach morphological changes, resulting in cover layer and berm erosion and offshore sediment transport, with rapid deposition in the beach backshore (Fig. 7).

Figure 8 compares simulated and observed bed level changes, showing that simulations reproduce the observed spatial variability along the beach with variable accuracy. As shown in Figure 9, the beach can 


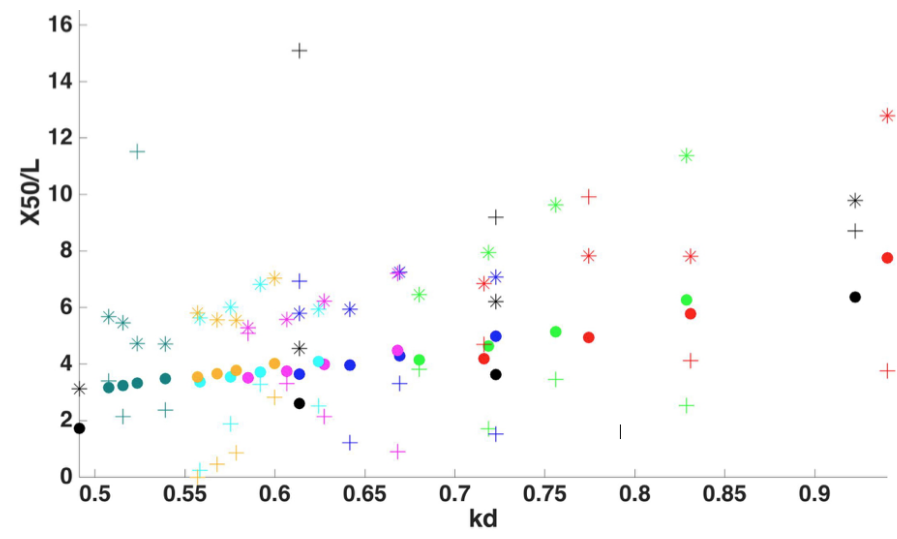

Figure 5: Non-dimensional distance across Spartina Alterniflora necessary to reduce the incident wave height by $50 \%$, with $d$ the water depth, $(k, L)$ the peak wavenumber and wavelength, and X50 the maximum depth-limited wave height (Smith et al. 2016).

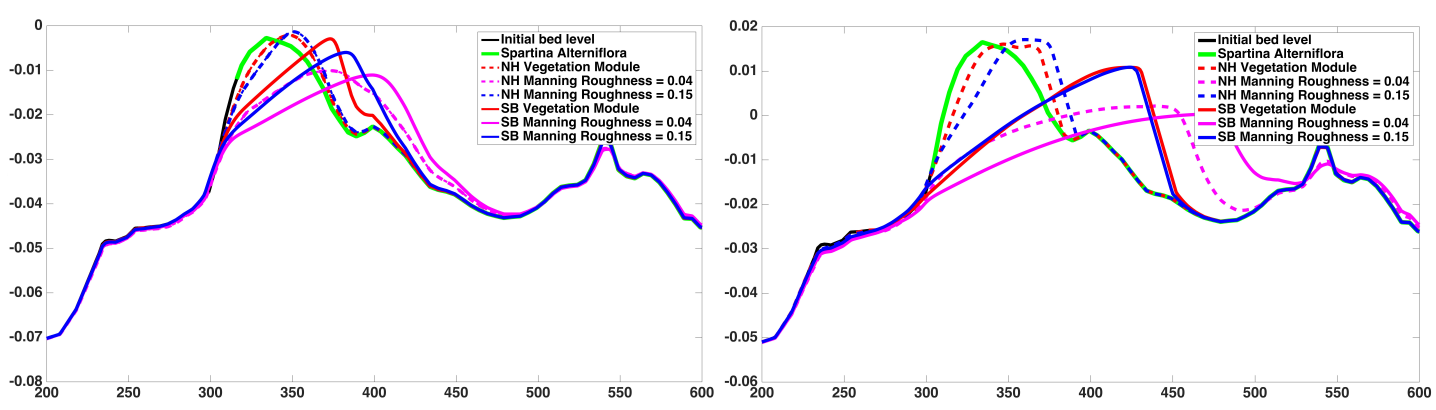

Figure 6: XBeach results for SB (left) and NH (right), showing bed level changes in meter for two different depths, using the vegetation module or different value of $n$ (bed friction).

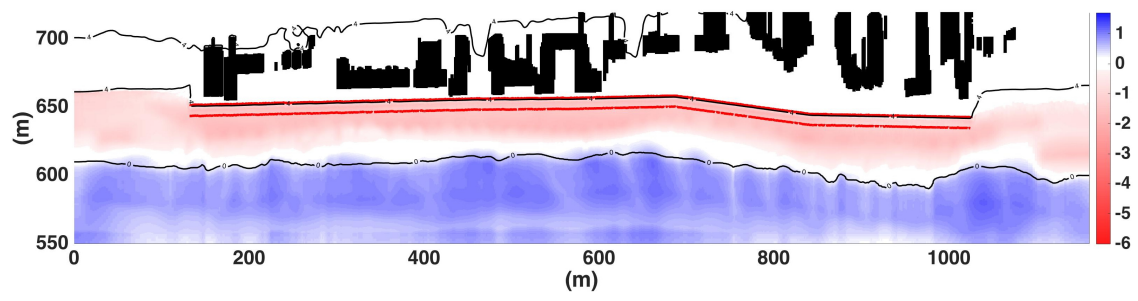

Figure 7: Bed level change (color scale in meter) modeled with XBeach at SIte 2, for TS Hermine. Red line marks location of GSC structure. Black shading refers to the location of buildings. Contour lines are shown for 0 and $4 \mathrm{~m}$.

be divided into 3 separate morphological sub-zones, each characterized by its observed behavior in erosion/accretion during TS Hermine and associated model performance. In Zone A, on the west side of the site, the observed accretion is poorly predicted by the model. Zone B, in the middle region, which shows exposure, is well predicted by the model. Zone $\mathrm{C}$, on eastern side of the beach, in which limited erosion is observed, is well predicted by the model. The model performance in terms of standard skill parameters, averaged for each morphological sub-zone, is summarized in Table 9. Zone A show a "poor" performance with large errors and low skill score. An "excellent" performance is obtained in Zone B, with an average of the Brier Skill Score (BSS = 0.83), indicating good morphological predictions. Eroded volumes were accurately calculated, resulting in a high Gallegher Skill Score $(\mathrm{SK}=0.63)$ and low Bias Score $(\mathrm{BI}=0.18$ $\mathrm{m})$. A Reasonable performance is achieved in Zone C, in which the non-exposure of the GSCs is correctly predicted, although the eroded volume is over estimated, leading to low scores. Figure 10 shows typical cross section profiles of bed level changes for each zone, which further illustrate the performance of the model. 


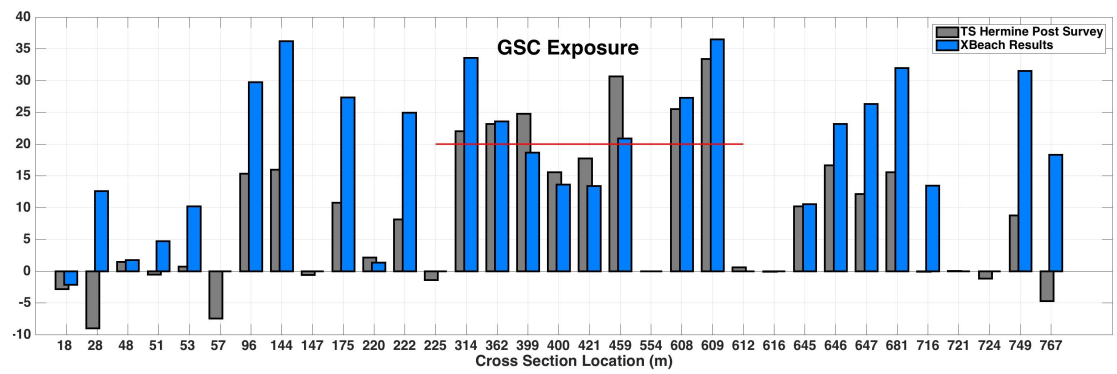

Figure 8: Comparison of measured eroded volumes in $\mathrm{m}^{3}$, with those modeled with XBeach at many transects along the length of the GSC structure. Red line indicates locations of GSC exposure; negative values indicate accretion.

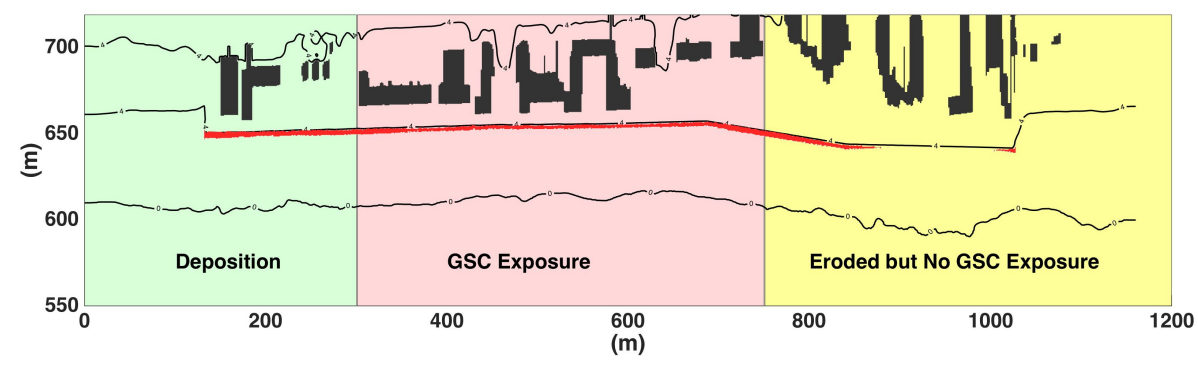

Figure 9: Zoning of Site 2. Red shading indicates exposed locations in XBeach simulations. Dark shading refers to building locations. Contour lines are shown for 0 and $4 \mathrm{~m}$.

Table 9: Summary of performance evaluation assessment for each zone in Site 2

\begin{tabular}{|c||c|c|}
\hline Zone A & Brier Skill Score (BSS) & -13.03 \\
(Area with Deposition) & Bias Score (BI) & $-0.41 \mathrm{~m}$ \\
& Root Mean Square (RMS) Error & $0.69 \mathrm{~m}$ \\
& Gallegher Skill Score (SK) & 0.26 \\
\hline Zone B & Brier Skill Score (BSS) & 0.83 \\
(GSC Exposure Area) & Bias Score (BI) & $0.18 \mathrm{~m}$ \\
& Root Mean Square (RMS) Error & $0.46 \mathrm{~m}$ \\
(Eroded Area but without Exposure) & Gallegher Skill Score (SK) & 0.67 \\
\hline Zone C & Brier Skill Score (BSS) & -3.25 \\
& Bias Score (BI) & $-0.27 \mathrm{~m}$ \\
& Root Mean Square (RMS) Error & $0.46 \mathrm{~m}$ \\
& Gallegher Skill Score (SK) & 0.30 \\
\hline
\end{tabular}

TS Hermine damage levels. Simulation results are used to predict damage levels at each location of the GSCs' structure (Table 2). Bed level changes are used to determine damage level on a 0-3 scale. For GSCs exposed locations hydraulic stability equations (Table 3) are applied to determine if damage level 4 is likely to occur. Damage level 5, is only calculated for GSCs located along the structure's toe. Maximum water levels are used to determine if damage level 6 is likely to occur. Figure 11 provides the estimated damage levels based on Oumeraci (2003) and Recio and Oumeraci's (2008) hydraulic stability equations.

The Hudson-based stability formula proposed by Oumeraci (2003) did not predict any GSC instability along the entire length of the structure. Recio and Omeraci's (2008) stability equation, however, predicted one unstable GSC occurring during peak conditions. Although one displaced GSC was also observed during survey measurements (Figure 12), the location of the predicted displaced bag was not accurately predicted in the model. Furthermore, damage 5 and 6 did not occur during TS Hermine, and was also not predicted by the model. 

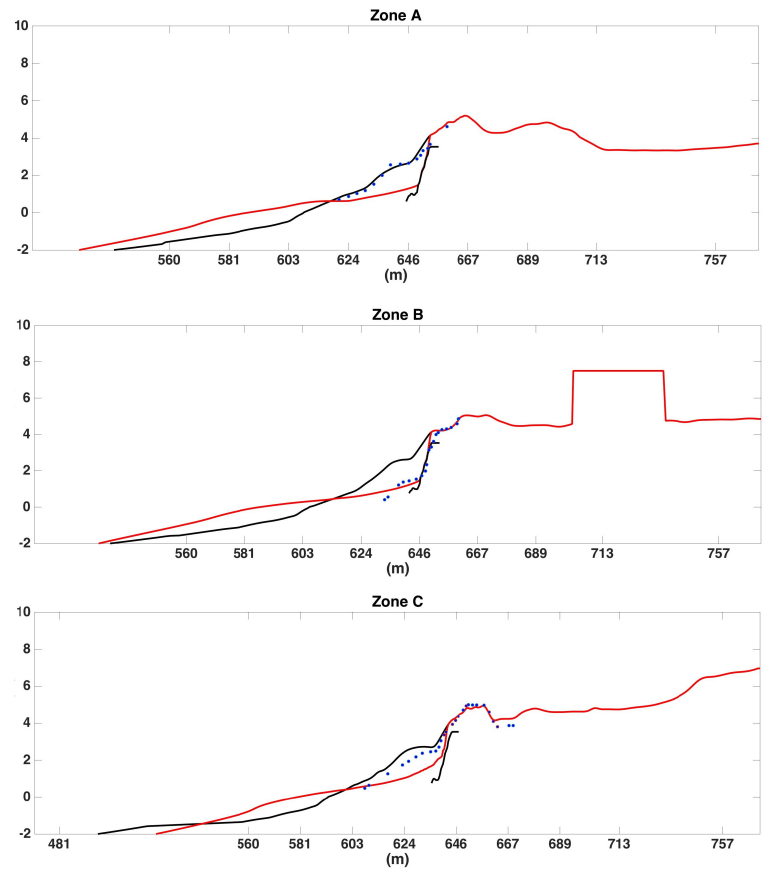

Figure 10: Typical cross-sectional profiles of bed level change in meter for each zones in SIte 2. Blue dots refer to post-measurements. Black lines indicate initial bed levels and red lines refer to XBeach results. The location of the GSC structure is also marked in black.

\section{DISCUSSION}

\section{Mitigating Erosion on Natural Barrier Islands with Vegetation}

Results of this study demonstrate the critical role of vegetated dunes in coastal protection. These natural structures generate friction and drag forces during cyclic loading, evolving in shape with the storm, acting as energy dissipators, minimizing storm impact and hence accelerating the restoration towards a stabilized environment. Indeed, the vegetation-induced increase in wave energy dissipation results in a reduced wave flow velocity field, limiting the wave momentum force on the dune as well as sediment pick-up and transport. The adequacy of the use of both wave model modes for simulating wave energy and forces as well as both vegetation models for simulating reacting forces are discussed in the following for each storm regimes.

Erosion modeling. The variability of dune crest elevation allows to assess the performance of the phaseresolving and phase-averaging hydro-morphodynamic models that are part of XBeach (i.e., Nonhydrostatic $(\mathrm{NH})$ and Surfbeat (SB) modes, respectively) for the 3 Sallenger storm regimes that occurred at Site 1 . In this comparison, the vegetation was modeled using the standard bed friction parameterization approach. Comparison of bed level changes for each regime, using the NH and SB modes indeed showed large discrepancies.

The ability of XBeach to model the morphological changes of beaches, barrier islands, and dunes has been well assessed in laboratory and field experiments, for the collision regime in dissipative beaches, with a surf similarity parameter ranging from 0 to 0.619 (e.g., Van Rooijen 2011; Roelvink et al. 2009, 2010; Nederhoff 2014; De Vet et al. 2015; Elsayed et al. 2017; Schambach et al. 2018). In this collision mode the foreshore erosion at the dune face is directly exposed to forcing from incident wave groups or "infragravity" waves, causing a slow oscillation of the mean super-elevated water level (Longuet-Higgins and Stewart, 1964). In dissipative beaches, the incident wave frequency band $(0.05<f<0.18 \mathrm{~Hz})$ is saturated, while the infra-gravity frequency band is not. Consequently, in the absence of incident-wave frequency band near the dune, both wave models tend to give similar performance with a "reasonable" BSS in Area A, characterized as the Sallenger collision regime zone.

In Area B, representative of the Sallenger overwash regime zone, differences between both wave models morphological predictions are observed. The NH mode leads to a higher BSS score, likely as a result of a better sediment spatial distribution pattern associated to a more accurate modeling of hydrodynamics 
a)

C)

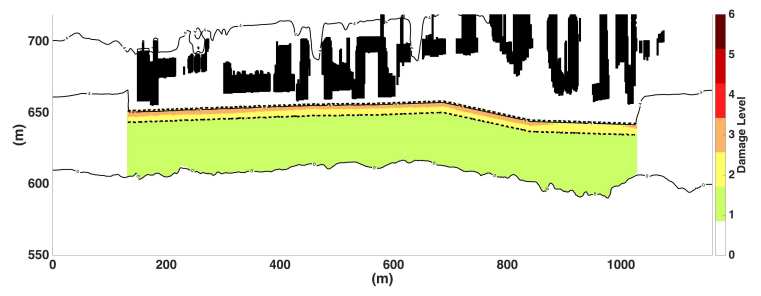

b)
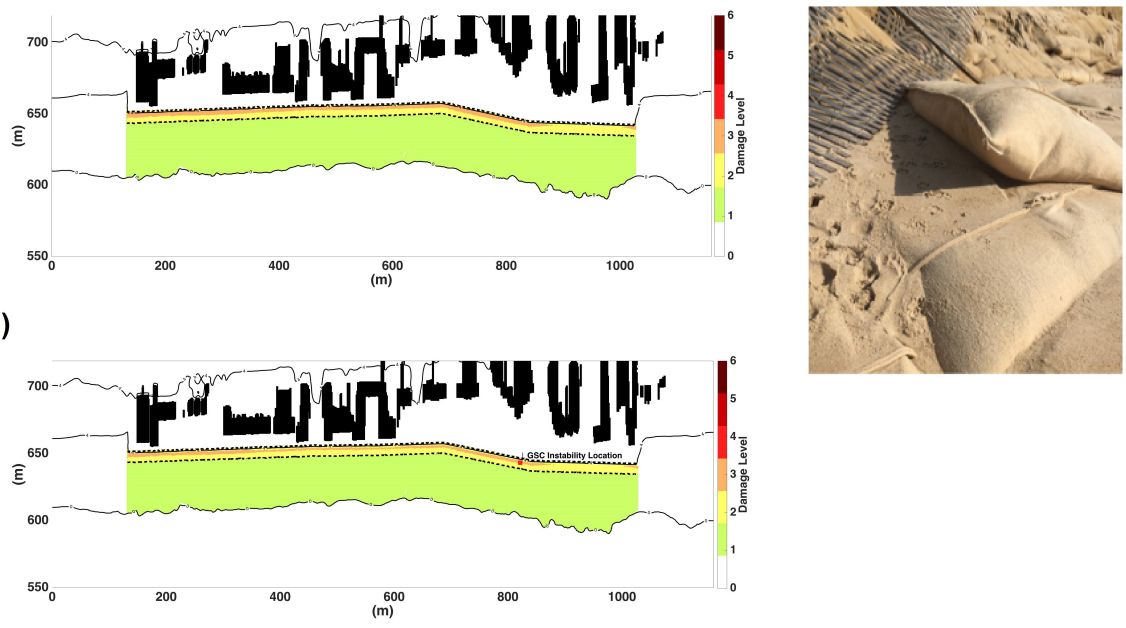

Figure 11: Calculated damage levels for TS Hermine at Site 2, using: a) Oumeraci et al. (2003) and b) Recio and Oumeraci (2007) hydraulic stability formulas for GSCs. c) Photo taken post-TS Hermine (2016) at Site 2, showing displacement of GSCs.

processes. However, the dune profile is more accurately simulated using the SB mode.

Similarly in Area C, characterized by a prevalence of Sallenger inundation regime due to the low dune crest elevation, the dune profile and the crest elevation are more accurately predicted using the SB mode (BSS $=0.19$ ). Indeed, the NH mode restricts the dune morphological evolution into Sallenger's inundation regime, therefore, the eroded volume is largely underestimated resulting in a lower BSS of -2.30 . This limited erosion consequently limits the sediment transport and prevents a large volume of sand to deposit landward. The SB mode however predicts the landward sediment deposition volume reasonably well, but the landward deposition distance is overestimated, possibly due to inaccurate estimation of water levels.

Vegetation modeling. The comparison of model results using Mendez and Losada's (2004) formulation and the standard bed friction parameterization shows significant differences. While morphological changes in the dune profile and crest elevation are reasonably predicted using the standard bed friction parameterization, the lack of a realistic drag force leads to overestimating flow velocity, which results in higher landward sediment deposition distances than observed. In contrast, Mendez and Losada's (2004) formulation provides a more accurate representation of the kinematic and dynamic free surface conditions over a vegetated field, as tested for Spartina Alterniflora, similar to Smith et al.'s (2016) results. However, that formulation significantly restricts the erosion rate of the barrier island at the test site, providing overall inaccurate morphological predictions. The presence of vegetation results in a nonlinear modulation to the velocity profiles (e.g., Maza et al. 2013; Vargas-Luna et al. 2015) which are not resolved in a 2D model such as XBeach (which has a single layer in the vertical direction). Resulting simplifications unfortunately counterbalance the interest of an a priori more accurate physics-based approach.

The current analysis at Site 1 confirms the relevance of using the hydro-morphodynamic model XBeach with the SB mode and a friction-based vegetation model to simulate the behavior of dissipative beaches in the NE Atlantic coastline (Schambach et al., 2018). It further demonstrates the prevalence of this combination SB-friction based vegetation model (FBVM) over more sophisticated approaches, to accurately predict the foreface dune erosion.

\section{Mitigating erosion on urbanized barrier islands with GSCs}

The combination SB-FBVM was used at Site 2 to assess the erosion around the GSC and the stability of the GSC using two types of hydraulic stability formulas. Both formulations had a similar adequacy to accurately assess the stability of the GSC, when used in combination with the hydro-morhodynamic model XBeach (i.e., damage level 4).

Performance of hydro-morphodynamic model. The model shows a good performance, particularly for the region of interest where the GSCs were exposed (Zone B). The simulated eroded volume in Zone A 
and $\mathrm{C}$ is however overestimated and the long-shore sediment transport and deposition on the west is not predicted. Let us add that the temporal variability of the bathy-topo induces a large uncertainty in the model initial conditions, which can lead to significant variations in the extend of the swash zone and, consequently, in the morphological changes of the beach.

Performance of hydraulic stability equations. Hudson's based stability equations underestimate the critical stability of the GSC at the site. Indeed, several locations were shown to be vulnerable during TS Hermine, which was not identified by Hudson's based stability equations. These equations estimate the stability as a function of the significant wave height at the toe of the structure. Throughout the storm regime, the water depth at that location remained very shallow, and thus most short waves were dissipated before reaching the site. The dominant velocities were therefore generated by the uprush and downrush of infragravity waves (e.g., Devet et al. 2015; Longuet-Higgins and Stewart, 1964).

The semi-empirical stability formulas such as introduced by Recio and Omeraci (2008) however suggest possible instabilities during TS Hermine, which was verified during the post-storm surveys. The applicability of these equations to this study remains however questionable, since Recio and Omeraci's (2008) hydraulic stability equations were validated for structures with 45 degrees slope (i.e., 1:1). The structure at the project site was constructed with a milder 1:2 slope, thus giving less contact area around the perimeter of the GSC. Different force coefficients calibration might be required for a 1:2 slope, since this increases the effective area and hence the resultant forces and moments.

\section{CONCLUSIONS}

The study evaluated several engineering tools for assessing the performance of two types of NNBFs in providing coastal protection services during extreme storm events along the US North Atlantic Coastline. The role of dunes and vegetated barrier islands to protect coastal communities against hurricanes and seasonal storms was first discussed. In RI, these remain the major factors to reduce damage levels associated with flooding and overtopping during overwash and inundation storm regimes (e.g., Grilli et al. 2017a, 2017b; Spaudling et al. 2016; Small et al. 2016; Schambach et al. 2018). The lack of comparative analysis with field data however limits the confidence onr can have in the approach.

The combination of hydro-morphodynamic and vegetation models available in XBeach were used to simulate morphological changes occurring at Site 1 during Hurricane Sandy (2012). The capability and limitation of each approach to model erosion and effects of vegetation on sediment transport, respectively, during 3 Sallenger storm regimes (2000) (i.e., collision, overwash, inundation) were identified when compared to pre- and post-storm measurement of bed level. XBeach's phase resolving mode (NH) provided better estimations of hydrodynamic conditions, leading to better sediment distribution patterns, but inaccurate estimation of erosion volumes, due to the incompatibility of the Van Theil (2009) - Van Rijin (2007) sediment concentration formulation requiring the orbital velocity. In contrast, XBeach's phase average (SB) mode provided better morphological predictions of the dune profile, leading to more accurate dune crest elevations, but overestimated the landward sediment deposition distance due to inaccurate hydrodynamic predictions. Depth-averaging introduced large modulation errors to the Generalized Langrangian Mean velocities, when using the vegetation module in XBeach, which limited its applicability and resulting accuracy. While the vegetation formulation introduced by Mendez and Losada (2004) simulated well the wave energy dissipation, its use in sediment transport provided poor morphological skill scores. The simple Manning roughness approach however provided optimal morphological predictions despite its underestimation of wave dissipation and correlated overestimation of wave velocities.

The second type of NNBF considered here, the reinforced dunes with GSCs as proposed for urbanized barrier islands with dissipative beaches and no protective buffer zones was explored for selected storm events at our test Site 2. The combination of XBeach with stability equations provided a numerical tool capable of identifying the damage states associated with these structures during storm events. The tool combines XBeach used in surf-beat mode (SB) with two hydraulic stability equations applied to the GSC: the Hudson (1956) based stability equation proposed by Oumeraci et al. (2003) and the more recent semiempirical equation proposed by Recio and Oumeraci (2008). XBeach was used to determine the initial damage states of erosion, while the hydraulic stability equations were used to determine the stability of exposed GSCs. The model was validated against post-storm measurements taken after TS Hermine, which caused exposure and minor damage to the GSC at Site 2. Results of bed level changes and eroded volume showed excellent performance in the region of interest, while some discrepancies occurred in other regions. 
Appropriate damage states, as occurred during the storm, were identified by the model and consisted mainly of berm and cover layer erosion, up to exposure of the GSC layer. The study indicated better confidence was obtained when using Recio and Omeraci (2008) stability equation for the exposed GSC, however, the validity of this equation to the configuration of the structure used in this study remains questionable.

\section{REFERENCES}

Anderson, M.E. and Smith, J.M., 2014. Wave attenuation by flexible, idealized salt marsh vegetation. Coastal Engng., 83, 82-92.

Arcement, G.J. and Schneider, V.R., 1989. Guide for selecting Manning's roughness coefficients for natural channels and flood plains.

Asano, T., Deguchi, H. and Kobayashi, N., 1993. Interaction between water waves and vegetation. In Coastal Engng. 1992 (pp. 2709-2723).

Booij, N., 1981. Gravity waves on water with non-uniform depth and current. Ph.D. Thesis Technische Hogeschool, Delft (Netherlands).

Blake, E.S., Kimberlain, T.B., Berg, R.J., Cangialosi, J.P. and Beven Ii, J.L., 2013. Tropical cyclone report: Hurricane sandy. National Hurricane Center, 12, pp.1-10.

Dalrymple, R.A., Kirby, J.T. and Hwang, P.A., 1984. Wave diffraction due to areas of energy dissipation. J. Waterway, Port, Coastal, Ocean Engng., 110(1), 67-79.

Dassanayake, D.T. and Oumeraci, H., 2013. Hydraulic stability formulae and nomograms for coastal structures made of geotextile sand containers. In Proc. 7th Intl. Conf. Asian and Pacific Coasts (pp. 24-26).

De Vet, P.L.M., McCall, R.T., Den Bieman, J.P., Stive, M.J. and Van Ormondt, M.A.A.R.T.E.N., 2015. Modelling dune erosion, overwash and breaching at Fire Island (NY) during Hurricane Sandy. In Proc. Coastal Sediments 2015.

De Vriend, H.J., J. Zyserman, J. Nicholson, J.A. Roelvink, P. Pechon, and H.N. Southgate. 1993. Medium-term 2DH coastal area modeling, Coastal Engng., 21, 193-224.

Elsayed, S.M. and Oumeraci, H., 2017. Effect of beach slope and grain-stabilization on coastal sediment transport: An attempt to overcome the erosion overestimation by XBeach. Coastal Engng., 121, 179-196.

Galappatti, G. and Vreugdenhil, C.B., 1985. A depth-integrated model for suspended sediment transport. J. Hydraulic Res., 23(4), 359-377.

Gallagher, E.L., Elgar, S. and Guza, R.T., 1998. Observations of sand bar evolution on a natural beach. J. Geophys. Res.: Oceans, 103(C2), 3203-3215.

Grilli, A.R., Spaulding, M.L., Schambach, L., Smith, J. and Bryant, M., 2017a. Comparing Inundation Maps Developed Using WHAFIS and STWAVE: A Case Study in Washington County, RI. Proc. ASCE conf.: Coastal Structures and Solutions to Coastal Disasters 2015: Resilient Coastal Communities.

Grilli, A.R., Spaulding, M.L., Oakley, B.A. and Damon, C., 2017b. Mapping the coastal risk for the next century, including sea level rise and changes in the coastline: application to Charlestown RI, USA. Nat. Haz., 88(1), 389-414.

Grilli, S.T., Grilli A.R., David, E. and C. Coulet 2016. Tsunami Hazard Assessment along the North Shore of Hispaniola from far- and near-field Atlantic sources. Nat. Haz., 82(2), 777-810.

Hudson, R.Y., 1959. Laboratory investigation of rubble-mound breakwaters. Reprint of original paper published in J. Waterways and Harbors Div. ASCE, proc. paper 2171.

Katehis, S., 2015. Validating the HAZUS Coastal Surge Model for Superstorm Sandy. Doctoral dissertation, University of Southern California.

Kothyari, U.C., Tiwari, A.K. and Singh, R., 1997. Estimation of temporal variation of sediment yield from small catchments through the kinematic method. Journal of hydrology, 203(1-4), pp. 39-57.

Longuet-Higgins, M.S. and Stewart, R.W., 1964, August. Radiation stresses in water waves; a physical discussion, with applications. Deep Sea Research and Oceanographic Abstracts, 11(4), 529-562.

Maza, M., Lara, J.L. and Losada, I.J., 2013. A coupled model of submerged vegetation under oscillatory flow using NavierĐStokes equations. Coastal Engng., 80, 16-34.

Mendez, F.J. and Losada, I.J., 2004. An empirical model to estimate the propagation of random breaking and nonbreaking waves over vegetation fields. Coastal Engng., 51(2), 103-118.

Möller, I. and Spencer, T., 2002. Wave dissipation over macro-tidal salt marshes: Effects of marsh edge typology and vegetation change. J. Coastal Res., 36(sp1), 506-521. 
Nederhoff, K., 2014. Modeling the effects of hard structures on dune erosion and overwash; hindcasting the impact of Hurricane Sandy on New Jersey with XBeach. MS thesis Delft Univ..

Oumeraci, H., Hinz, M., Bleck, M. and Kortenhaus, A., 2003. Sand-filled geotextile containers for shore protection. COPEDEC VI, Colombo, Sri Lanka.

Recio, J. and Oumeraci, H., 2007. Effect of deformations on the hydraulic stability of coastal structures made of geotextile sand containers. Geotextiles and geomembranes, 25(4-5), pp.278-292.

Recio, J.A. and Oumeraci, H., 2008. Hydraulic stability of geotextile sand containers for coastal structures. PhD-Thesis Univ. of Braunschweig, Faculty of Architec., Civil Engng. and Environ.

Recio, J. and Oumeraci, H., 2009. Hydraulic stability of geotextile sand containers for coastal structureseffect of deformations and stability formulae. In Coastal Engng. 2008: (In 5 Volumes) (pp. 3805-3817).

Roelvink, D., Reniers, A., Van Dongeren, A.P., de Vries, J.V.T., McCall, R. and Lescinski, J., 2009. Modeling storm impacts on beaches, dunes and barrier islands. Coastal Engng., 56(11-12), 1133-1152.

Roelvink, D., Reniers, A.J.H.M., Van Dongeren, A., Van Thiel de Vries, J., Lescinski, J. and McCall, R., 2010. XBeach model description and manual. Unesco-IHE Institute for Water Education, Deltares and Delft University of Tecnhology. Report June, 21, p.2010.

Sallenger Jr, A.H., 2000. Storm impact scale for barrier islands. J. Coastal Res., pp.890-895.

Schambach, L., Grilli, A.R., Grilli, S.T., Hashemi, M.R. and King, J.W., 2018. Assessing the impact of extreme storms on barrier beaches along the Atlantic coastline: Application to the southern Rhode Island coast. Coastal Engng., 133, 26-42.

Smith, J.M., Bryant, M.A. and Wamsley, T.V., 2016. Wetland buffers: numerical modeling of wave dissipation by vegetation. Earth Surface Processes and Landforms, 41(6), 847-854.

Spaulding, M.L., Grilli, A.R., Damon, C., Crean, T., Fugate, G., Oakley, B.A. and Stempel, P., 2016. STORMTOOLS: coastal environmental risk index (CERI). J. Marine Sc. and Engng., 4(3), 54.

Spaulding, M.L., Grilli, A.R., Damon, C., Fugate, G., Isaji, T. and Schambach, L., 2017. Application of State of the Art Modeling Techniques to Predict Flooding and Waves for a Coastal Area within a Protected Bay. J. Marine Sc. and Engng., 5(1), 14.

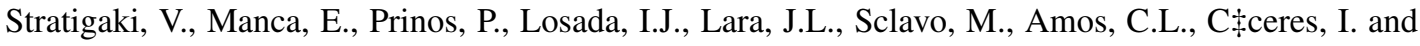
Słnchez-Arcilla, A., 2011. Large-scale experiments on wave propagation over Posidonia Oceanica. $J$. Hydraulic Res., 49(sup1), 31-43.

Terrados, J. and Duarte, C.M., 2000. Experimental evidence of reduced particle resuspension within a seagrass (Posidonia oceanica L.) meadow. J. Exp. Marine Biology and Ecology, 243(1), 45-53.

USACE-NAN, 2014. Downtown Montauk Stabilization Project: Hurricane Sandy Limited Reevaluation Report. U.S. Army Corps of Engineers, New York District.

Van Rijn, L.C., 1989. The state of the art in sediment transport modeling. In Sediment Transport Modeling (pp. 13-32). ASCE.

Van Rijn, L.C., Walstra, D.J.R., Grasmeijer, B., Sutherland, J., Pan, S. and Sierra, J.P., 2003. The predictability of cross-shore bed evolution of sandy beaches at the time scale of storms and seasons using process-based profile models. Coastal Engng., 47(3), 295-327.

Van Rijn, L.C., 2007. Unified view of sediment transport by currents and waves. I: Initiation of motion, bed roughness, and bed-load transport. J. Hydraulic Engng., 133(6), 649-667.

Van Rooijen, A.A., 2011. Modelling sediment transport in the swash zone.

Van Thiel de Vries, J.S.M., 2009. Dune erosion during storm surges.

Vargas-Luna, A., Crosato, A. and Uijttewaal, W.S., 2015. Effects of vegetation on flow and sediment transport: comparative analyses and validation of predicting models. Earth Surface Processes and Landforms, 40(2), 157-176.

Wamsley, T.V., Cialone, M.A., Smith, J.M., Ebersole, B.A. and Grzegorzewski, A.S., 2009. Influence of landscape restoration and degradation on storm surge and waves in southern Louisiana. Nat. Haz., 51(1), 207-224.

Wamsley, T.V., Cialone, M.A., Smith, J.M., Atkinson, J.H. and Rosati, J.D., 2010. The potential of wetlands in reducing storm surge. Ocean Engng., 37(1), 59-68.

Woodhouse, W.W., 1978. Dune building and stabilization with vegetation. Spl. Rep. no. 3. US Army Corps of Engineers, Fort Belvoir, Virginia.

Woodruff, J.D., Irish, J.L. and Camargo, S.J., 2013. Coastal flooding by tropical cyclones and sea-level rise. Nature, 504(7478), 44. 